\title{
Coastal Mudflat Saline Soil Amendment by Dairy Manure and Green Manuring
}

\author{
Yanchao Bai, ${ }^{1,2,3}$ Yiyun Yan, ${ }^{1}$ Wengang Zuo, ${ }^{1}$ Chuanhui Gu, ${ }^{4}$ Weijie Xue, ${ }^{1}$ Lijuan Mei, ${ }^{1}$ \\ Yuhua Shan, ${ }^{1,5}$ and Ke Feng ${ }^{1,5}$ \\ ${ }^{1}$ College of Environmental Science and Engineering, Yangzhou University, Yangzhou 225009, China \\ ${ }^{2}$ State Key Laboratory of Soil and Sustainable Agriculture, Institute of Soil Science, Chinese Academy of Sciences, \\ Nanjing 210008, China \\ ${ }^{3}$ Institute of Biotechnology, Jiangsu Academy of Agricultural Sciences, Nanjing 210014, China \\ ${ }^{4}$ Department of Geology, Appalachian State University, Boone, NC 28608, USA \\ ${ }^{5}$ Jiangsu Collaborative Innovation Center for Solid Organic Waste Resource Utilization, Nanjing 210095, China
}

Correspondence should be addressed to Yanchao Bai; byc529@gmail.com and Yuhua Shan; shanyuhua@outlook.com

Received 18 December 2016; Revised 23 January 2017; Accepted 2 February 2017; Published 21 February 2017

Academic Editor: Mathias N. Andersen

Copyright (C) 2017 Yanchao Bai et al. This is an open access article distributed under the Creative Commons Attribution License, which permits unrestricted use, distribution, and reproduction in any medium, provided the original work is properly cited.

Dairy manure or green manuring has been considered as popular organic amendment to cropland in many countries. However, whether dairy manure combined with green manuring can effectively amend mudflat saline soil remains unclear. This paper was one of first studies to fill this knowledge gap by investigating impact of dairy manure combined with green manuring on soil chemical properties of mudflat saline soil. Dairy manure was used by one-time input, with the rates of $0,30,75,150$, and 300 tha $^{-1}$, to amend mudflat saline soil. Ryegrass, Sesbania, and ryegrass were chosen as green manures for three consecutive seasons, successively planted, and tilled, and maize was chosen as a test crop. The results indicated that one-time application of dairy manure enhanced fertility of mudflat saline soil and supported growth of ryegrass as the first season green manure. By the cycles of the green manuring, it rapidly improved the chemical properties of mudflat saline soil by decreasing soil salinity and $\mathrm{pH}$ and increasing soil organic carbon and available N and P, which promoted growth of maize. Dairy manure combined with green manuring can be applied for mudflat saline soil amendment, which provides an innovative solution for mudflat saline soil reclamation, dairy manure disposal, and resource recycling.

\section{Introduction}

Coastal mudflats located in the interaction zone between land and sea are found in many parts of the world [1]. According to statistics, there are $10000 \mathrm{~km}^{2}$ coastal mudflat along the east coast of China. More than $6500 \mathrm{~km}^{2}$ and $3500 \mathrm{~km}^{2}$ mudflat mainly located in the Yangtze River Estuary of western Yellow Sea and the Yellow River Delta of western Bohai Sea, respectively. The mudflats can be important alternative sources for arable lands after being amended by large amount of organic fertilizers. About 1.1 1.2 million ha mudflats have been reclaimed to croplands in the past 50 years [2]. It is estimated that additional $2000 \mathrm{~km}^{2}$ mudflats will be reclaimed to cropland in 2020s, according to the policy of coastal development planning in Jiangsu province in China, and another $4400 \mathrm{~km}^{2}$ in the Yellow River Delta are under discussion [3]. The newly reclaimed mudflats as typical saline soils are not suitable for cultivation due to high salinity and macronutrient deficiencies, which hinder the germination and growth of plants [4]. The key to improve the newly reclaimed mudflats is to increase the soil organic matter (OM) content for fertility enhancement and salinity reduction [5-7], which is usually achieved through instantaneous application of a great amount of organic matter because soil natural organic matter formation is extremely slow.

Dairy manure generated in dairy industry is rich in $\mathrm{OM}$ and inorganic nutrients and has caused serious 
environmental pollution and ecological safety concern. Therefore, mudflat saline soil that needs organic amendment may become a potential land source for safe disposal of massive dairy manure, which also has a great incentive in view of mudflat saline soil amendment, and nutrient recycling and reuse including $\mathrm{OM}$, nitrogen $(\mathrm{N})$, phosphorus (P), and other plant nutrients. Moreover, it is well known that cultivation of green manures plays an important role in soil quality and sustainability of agricultural systems and has been used to increase the soil fertility, as it adds organic carbon and nutrients to the soil [8]. Green manures were tilled into soil to increase soil OM content, which improved soil bulk density, soil porosity, soil structure, and water holding capacity $[9,10]$. Input of biomass of green manures can facilitate mineralization, which enhanced soil fertility [11]. To amend saline agricultural soils, different green manure, such as straw, cotton, and maize, have been applied to increase soil OM $[12,13]$.

Past research on the application of dairy manure for soil amendment has mainly focused on farmlands [14-16], which showed that land application of dairy manure increased soil OM [17], yield of plants [18, 19]. However, the mudflat saline soil amended by dairy manure and green manure has received no attention. The effect and mechanism of dairy manure amendment on mudflat saline soil can be quite different because farmlands are different from mudflats in soil structure, nutrient, microbial flora, and so forth $[1,20]$.

In this study, we aimed to assess the method for mudflat saline soil amendment by dairy manure and green manuring. Dairy manure was used by one-time application to amend infertile mudflat saline soil and to support growth of green manure at the first season. Then, green manure tilled into mudflat saline soil can be decomposed and converted into soil $\mathrm{OM}$. By the cycles of planting and tilling green manures, OM in mudflat saline soil would rapidly increase through buildup added organic matter. However, whether dairy manure and green manuring can effectively amend mudflat saline soil remains unclear. This paper was one of first studies to fill this knowledge gap by assessing the effects of dairy manure combined with green manuring on the change of organic carbon, salinity, $\mathrm{pH}$, and $\mathrm{N}$ and $\mathrm{P}$ of mudflat saline soil, as well as the yield and metal uptake of maize (Zea mays L.) as a test crop. Our goals are to assess the effects of dairy manure combined with green manuring on mudflat saline soil chemical properties and crop yield, and to assure environmental safety for heavy metals in crops grown in mudflats.

\section{Materials and Methods}

2.1. Study Area and Experimental Materials. The experiment was conducted at the farm of Senmao Company Ltd. located in Rudong county, Jiangsu Province, China (E $121^{\circ} 24^{\prime} 04^{\prime \prime}$, $\left.\mathrm{N} 32^{\circ} 20^{\prime} 00^{\prime \prime}\right)$. The land, as reclaimed from coastal mudflats by building an artificial seawall in 2007 to prevent seawater intrusion, is under amendment since 2011. The distance from the site to the new Yellow Sea coastline (the artificial seawall) is approximately $1.2 \mathrm{~km}$. The experimental mudflat soil was
TABLE 1: Basic chemical properties of the mudflat saline soil at the start of the experiment and dairy manure used in this study.

\begin{tabular}{lcc}
\hline Parameters & Mudflat saline soil & $\begin{array}{c}\text { Dairy } \\
\text { manure }\end{array}$ \\
\hline pH & 8.92 & 7.74 \\
Salinity (\%o) & 8.82 & 11.61 \\
Organic matter $\left(\mathrm{g} \mathrm{kg}^{-1}\right)$ & 3.16 & 415.7 \\
Total N $\left(\mathrm{N} \mathrm{g} \mathrm{kg}^{-1}\right)$ & 0.209 & 32.3 \\
Total P $\left(\mathrm{P} \mathrm{g} \mathrm{kg}^{-1}\right)$ & 0.565 & 5.31 \\
Alkaline N $\left(\mathrm{N} \mathrm{mg} \mathrm{kg}^{-1}\right)$ & 17.48 & 358.1 \\
Available P $\left(\mathrm{P} \mathrm{mg} \mathrm{kg}^{-1}\right)$ & 17.86 & 111.9 \\
Total Cd $\left(\mathrm{mg} \mathrm{kg}^{-1}\right)$ & 0.451 & 2.15 \\
Total Cr $\left(\mathrm{mg} \mathrm{kg}^{-1}\right)$ & 13.08 & 41.7 \\
Total Cu $\left(\mathrm{mg} \mathrm{kg}^{-1}\right)$ & 15.89 & 769.4 \\
Total Mn $\left(\mathrm{mg} \mathrm{kg}^{-1}\right)$ & 152.8 & 133.9 \\
Total Ni $\left(\mathrm{mg} \mathrm{kg}^{-1}\right)$ & 30.4 & 18.0 \\
Total $\mathrm{Zn}\left(\mathrm{mg} \mathrm{kg}^{-1}\right)$ & 49.9 & 146.7 \\
\hline
\end{tabular}

typic saline soil, which belonged to the halaquepts group of aquepts in inceptisols based on US soil taxonomy. The experimental dairy manure was collected from the Dairy Farm of Rudong County in September 2011. The chemical properties of mudflat soil and dairy manure were shown in Table 1.

2.2. Experimental Design. The experiment was carried out in randomized complete block design with each plot of $4 \mathrm{~m}$ length and $4 \mathrm{~m}$ width. The average OM content in arable lands soil was about $0.5 \%-3.0 \%$ of total soil weight. Therefore, 30 , 75,150 , and $300 \mathrm{tha}^{-1}(0.5 \%, 1.0 \%, 1.5 \%$, and $3.0 \%$ organic matter of total soil weight, resp.) dairy manure amendment (DMA) rates on a dried weight basis by one-time application were used. The unamended soil was the control soil. Each of the five treatments had three replicates. The dairy manure was mixed uniformly with soil down to the depth of $20 \mathrm{~cm}$ by a rototiller on 20th October 2011. Ryegrass (Lolium perenne L.) as a popular high-quality and salt-tolerant green manure was chosen for the first season green manure, sowed $35 \mathrm{~g}$ for each plot in 25th October 2011, and tilled in 30th May 2012. Sesbania (Sesbania cannabina) as the second season green manure was sowed $120 \mathrm{~g}$ for each plot in 12th June 2012 and tilled in 20th September 2012. Ryegrass as the third season green manure was sowed in 30th October 2012 and tilled in 25th May 2013. Maize (Zea mays L.) as one of the most important grain crop in China was chosen as a test crop, sowed two seeds per hole with average row spacing of $0.50 \mathrm{~m}$ and plant spacing of $0.25 \mathrm{~m}$ in 10th July 2013, and harvested in 22th September 2013. Thinning was carried out 20 days after sowing (DAS), leaving one plant per hole. Weeding was carried out two times during the whole experiment, 20 and 48 DAS, through hand-hoeing. Plants were rain-fed, and no extra artificial irrigation was carried out. Soil and plant samples were collected for analysis in 30th May and 20th September 2012 and 25th May and 22th September 2013. 
2.3. Soil Analysis. Soil samples for $0-20 \mathrm{~cm}$ depth were collected in quadruplicate from control, 30, 75, 150, and $300 \mathrm{tha}^{-1}$ DMA rates. For analysis of organic carbon (OC), $0.3 \mathrm{~g}$ air-dried sample through $0.150 \mathrm{~mm}$ mesh size was measured by the $\mathrm{K}_{2} \mathrm{Cr}_{2} \mathrm{O}_{7}$ method. Soil salinity was measured by the gravimetric method. The $\mathrm{pH}$ of soil was measured in suspension of $1: 5$ (weight/volume) by $\mathrm{pH}$ meter (Model IQ150, Spectrum, USA). Alkaline N was determined by alkaline hydrolysis diffusion method. Available $\mathrm{P}$ was analyzed by sodium bicarbonate $\left(\mathrm{NaHCO}_{3}\right)$ extraction and subsequent colorimetric analysis. The analytical methods for the above soil chemical properties are described in detail by the Soil and Agro-Chemistry Analysis [21].

2.4. Plant Analysis. The biomasses of green manures for three consecutive seasons and maize were determined by weighting all biomass from each plot after harvesting. For estimation of aerial part growth, 10 plants of maize were sampled randomly from each plot and then washed with deionized water to remove soil particles adhering on them, separated into stem, leaves, husk, cob, and grain parts, deactivated at $105^{\circ} \mathrm{C}$ for 15 minutes, and oven-dried at $80^{\circ} \mathrm{C}$ until constant weight was achieved. The plant parts were then weighed separately and biomass accumulation was expressed as grams per plant. For extraction of metals (Cd, Cr, Cu, Mn, $\mathrm{Ni}$, and $\mathrm{Zn}$ ) in maize grain, $0.5 \mathrm{~g}$ oven-dried sample was digested in $10 \mathrm{~mL}$ tri acid mixture $\left(\mathrm{HNO}_{3} / \mathrm{H}_{2} \mathrm{SO}_{4} / \mathrm{HClO}_{4}, 5: 1: 1\right)$ till transparent color appeared. Metal concentrations were determined after filtering the digested samples by using Atomic Absorption Spectrometer (Model SOLAAR M6, Thermo Elemental, Thermo Fisher Scientific Inc., USA).

2.5. Statistical Analysis. After tests of normality of data distribution and homogeneity of variance among treatments, analysis of variance (ANOVA) of monofactorial (DMA) for randomized complete block design was conducted using SPSS version 13 software. Then, the least significant difference (LSD) method at the 0.05 level of significance was performed to test the significant difference between the treatments.

\section{Results}

3.1. Biomass of Green Manures and Maize. The DMA significantly increased biomass of ryegrass, Sesbania, ryegrass, and maize grown in mudflat saline soil, and the biomass of all plants increased with increasing DMA rates (Figure 1). The biomass of three green manures increased by $35.9 \%-$ $87.3 \%, 56.2 \%-119.8 \%, 77.0 \%-169.7 \%$, and $141.3 \%-223.0 \%$ at $30,75,150$, and $300 \mathrm{tha}^{-1}$ DMA rates, respectively, compared to the unamended soil. The dairy manure combined with green manuring significantly increased biomass of maize at all DMA rates $(p<0.05)$, and maize biomass in the mudflat saline soil increased with increasing DMA rate. There were increments in maize biomass by $44.4 \%, 117.1 \%, 142.2 \%$, and $214.9 \%$ at $30,75,150$, and $300 \mathrm{tha}^{-1}$ DMA rates, respectively, compared to $29.35 \mathrm{~kg} \mathrm{plot}^{-1}$ in the unamended soil.

3.2. Soil Chemical Properties. The DMA significantly increased organic carbon concentration in mudflat saline

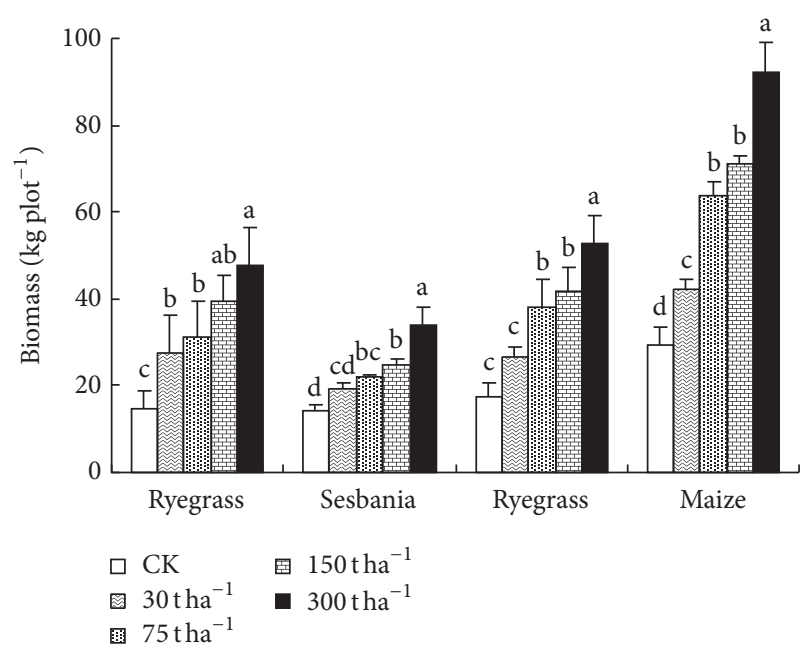

FIGURE 1: Effects of dairy manure amendment on biomass of green manures and maize. Vertical bars indicate standard deviations of the means. Columns with different letters show significant difference between dairy manure amendment rates at $p<0.05$ by LSD's multiple range test.

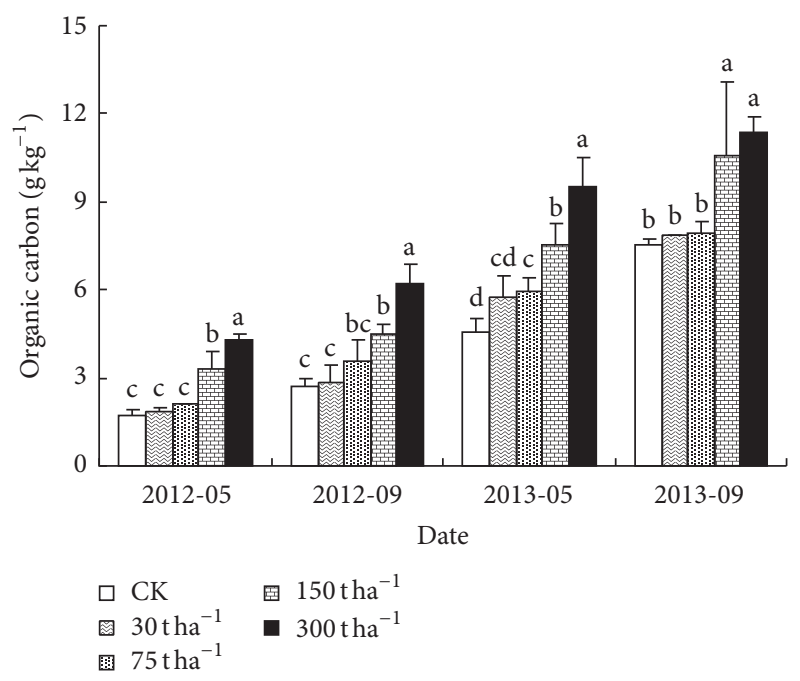

FIGURE 2: Effects of dairy manure amendment on organic carbon in mudflat saline soil. Vertical bars indicate standard deviations of the means. Columns with different letters show significant difference between dairy manure amendment rates at $p<0.05$ by LSD's multiple range test.

soil, and the OC concentration in the topsoil at all DMA rates increased over time (Figure 2). The dairy manure combined with green manuring significantly increased OC concentration by $4.1 \%-26.7 \%, 5.4 \%-32.2 \%, 40.6 \%-92.2 \%$, and $51.2 \%-151.1 \%$ at $30,75,150$, and $300 \mathrm{tha}^{-1}$ DMA rates in the four experimental dates, respectively, compared to the unamended soil. The increments of OC concentration were $36.1 \%, 33.0 \%, 39.8 \%$, and $19.8 \%$ at $30,75,150$, and $300 \mathrm{tha}^{-1}$ DMA rates in September 2013, respectively, compared to May 2013. 


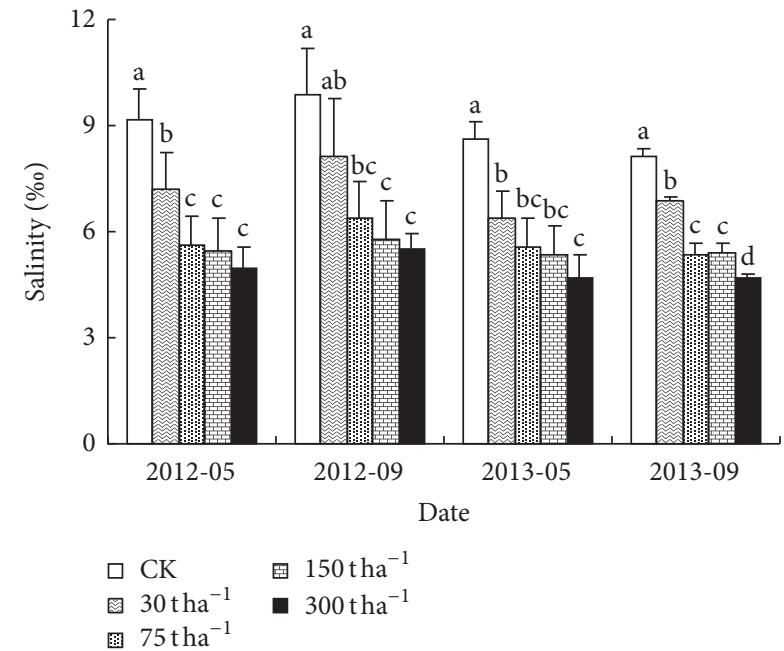

(a)

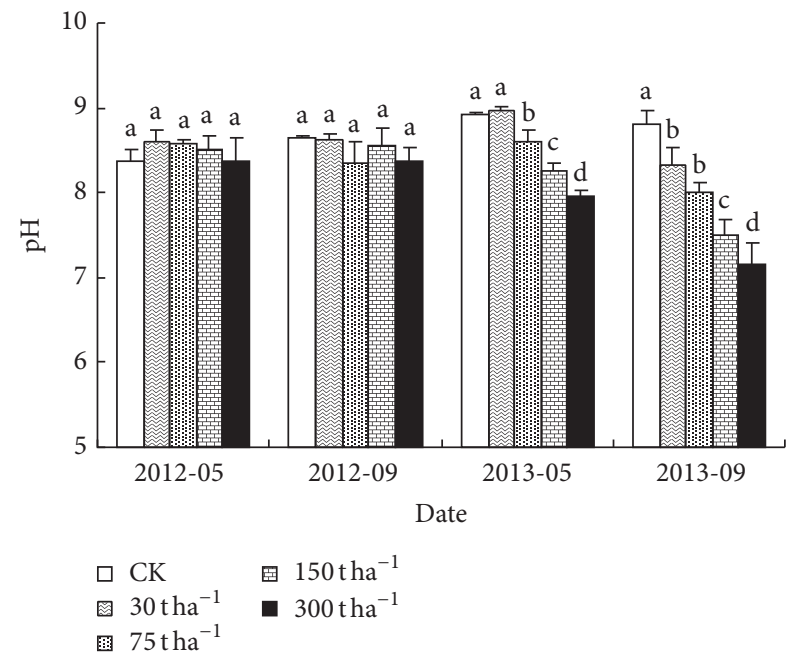

(b)

Figure 3: Effects of dairy manure amendment on salinity (a) and pH (b) in mudflat saline soil. Vertical bars indicate standard deviations of the means. Columns with different letters show significant difference between dairy manure amendment rates at $p<0.05$ by LSD's multiple range test.

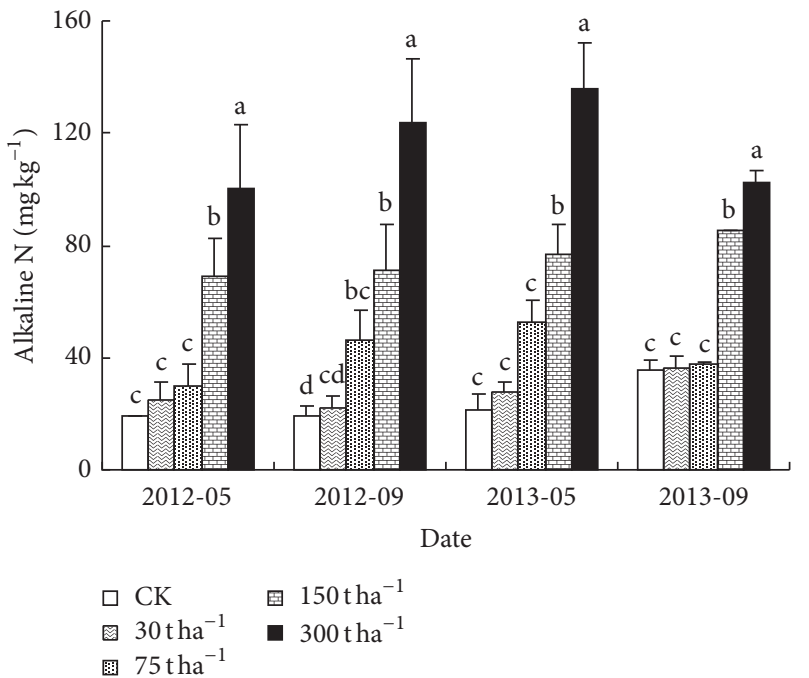

(a)

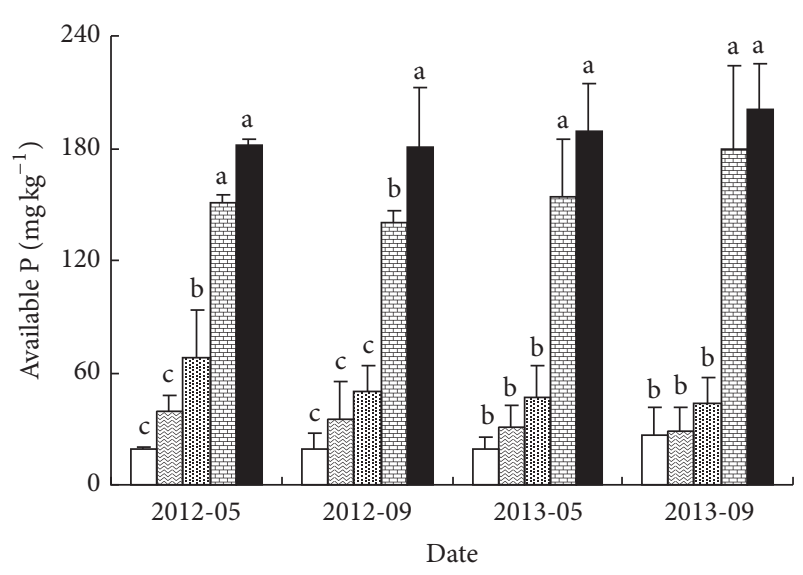

$\begin{array}{ll}\square \mathrm{CK} & \text { ⿴囗十 } 150 \mathrm{tha}^{-1} \\ \text { 圆 } 30 \mathrm{tha}^{-1} & \mathbf{\square} 300 \mathrm{tha}^{-1} \\ \text { 圂 } 75 \mathrm{tha}^{-1} & \end{array}$

(b)

FIGURE 4: Effects of dairy manure amendment on concentrations of alkaline nitrogen (a) and available phosphorus (b) in mudflat saline soil. Vertical bars indicate standard deviations of the means. Columns with different letters show significant difference between dairy manure amendment rates at $p<0.05$ by LSD's multiple range test. $\mathrm{N}$, nitrogen; $\mathrm{P}$, phosphorus.

The DMA significantly decreased salinity in mudflat saline soil, and salinity decreased with increasing DMA rates in the four experimental dates (Figure 3(a)). However, the green manuring did not significantly change soil salinity. The salinity decreased by $15.0 \%-26.1 \%, 34.0 \%-38.4 \%, 33.7 \%-$ $41.3 \%$, and $42.1 \%-45.9 \%$ at $30,75,150$, and $300 \mathrm{tha}^{-1}$ DMA rates in the four experimental dates, respectively, compared to the unamended soil.

The application of dairy manure did not significantly affect $\mathrm{pH}$ in mudflat saline soil, and the $\mathrm{pH}$ decreased with increasing biomass of tilled green manures in May and September 2013 (Figure 3(b)). The $\mathrm{pH}$ decreased by $3.1 \%-5.3 \%, 7.1 \%-9.0 \%, 10.7 \%-14.7 \%$, and $14.1 \%-18.8 \%$ at $30,75,150$, and $300 \mathrm{tha}^{-1}$ DMA rates in May and September 2013, respectively, compared to the unamended soil.

The dairy manure combined with green manuring significantly increased alkaline $\mathrm{N}$ and available $\mathrm{P}$ in mudflat saline soil, and the concentrations of alkaline $\mathrm{N}$ and available $\mathrm{P}$ in the soil increased with increasing DMA rates at the four experimental dates (Figure 4). The alkaline $\mathrm{N}$ and available $\mathrm{P}$ increased by $2.8 \%-38.7 \%, 5.9 \%-144.0 \%, 142.2 \%-280.1 \%$, and $190.7 \%-544.2 \%$ and $6.3 \%-112.3 \%, 61.7 \%-264.7 \%, 568.8 \%-$ $707.0 \%$, and $648.0 \%-872.7 \%$ at $30,75,150$, and $300 \mathrm{tha}^{-1}$ DMA rates in the four experimental dates, respectively, compared to the unamended soil. 


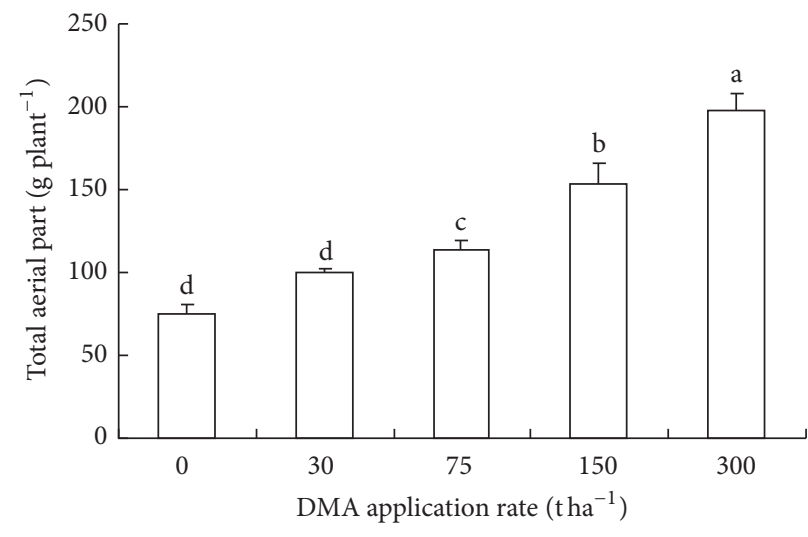

(a)

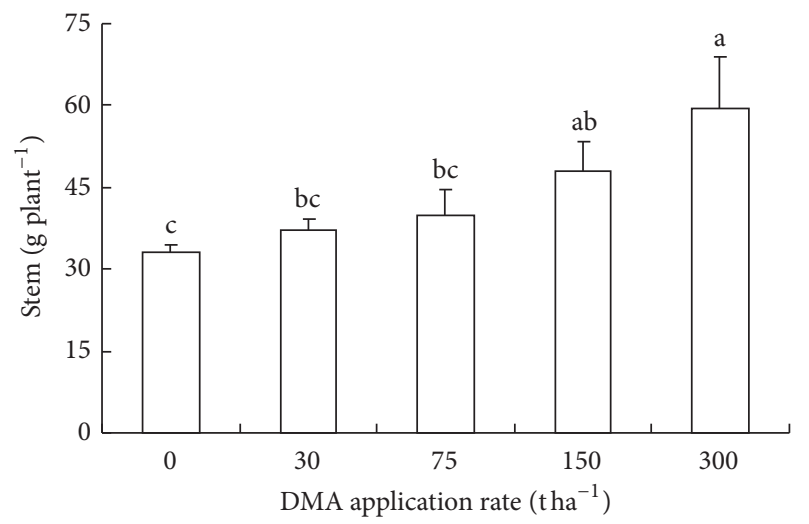

(c)

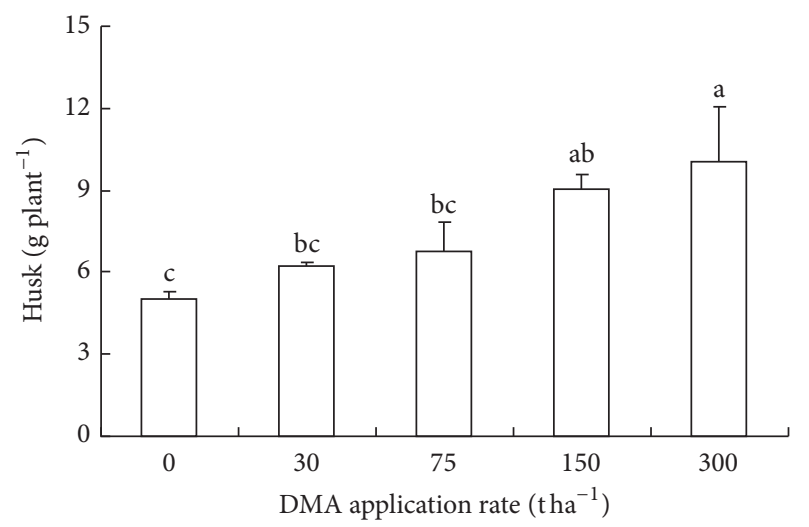

(e)

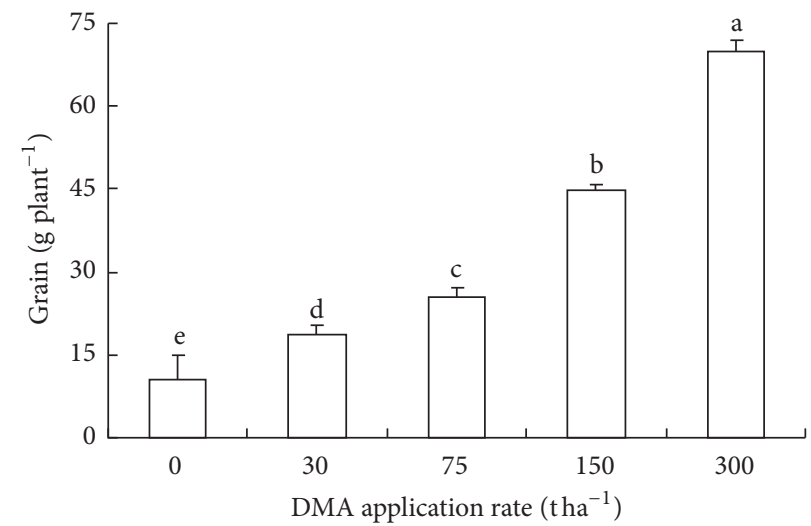

(b)

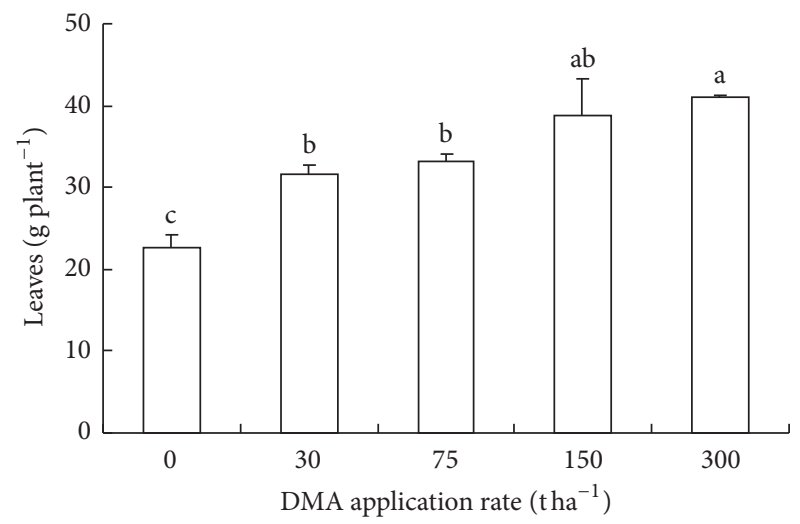

(d)

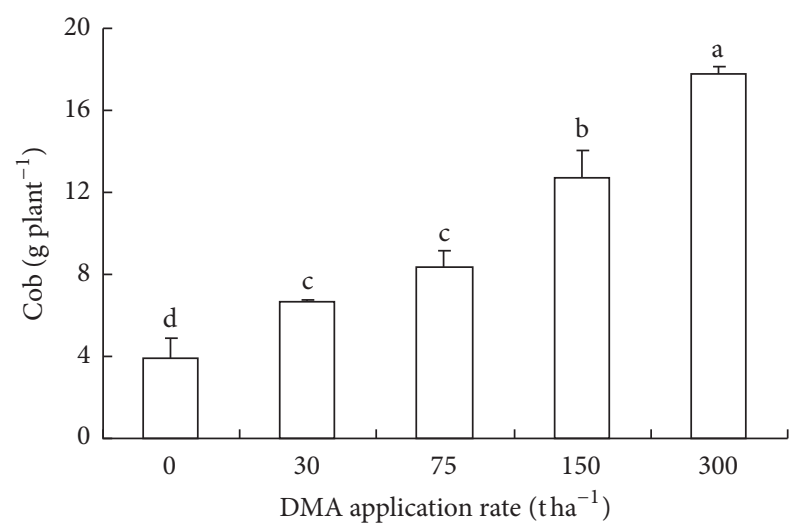

(f)

FIGURE 5: Effects of dairy manure amendment (DMA) on dry matter for total aerial part (a), grain (b), stem (c), leaves (d), husk (e), and cob (f) of maize grown in mudflat saline soil. Vertical bars indicate standard deviations of the means. Columns with different letters show significant difference between dairy manure amendment rates at $p<0.05$ by LSD's multiple range test.

3.3. Dry Matter of Maize. Dry matter of total aerial part increased with increasing DMA rates and was significantly higher at all DMA soils than the unamended soil (Figure $5(\mathrm{a}))$. Grain yield of maize at $30,75,150$, and $300 \mathrm{tha}^{-1}$ DMA rates increased by $78.6 \%, 141.6 \%, 323.5 \%$, and $562.2 \%$, respectively, as compared to $10.54 \mathrm{~g} \mathrm{plant}^{-1}$ in the unamended soil (Figure 5(b)). Dry matter for stem, leaves, husk, and cob of maize in mudflat saline soil significantly increased with increasing DMA rates (Figures 5(c)-5(f)). Stem and husk dry matter at 150 and $300 \mathrm{tha}^{-1}$ DMA rates were 47.86 ,
$59.58 \mathrm{~g} \mathrm{plant}^{-1}$ and 9.01, $10.07 \mathrm{~g} \mathrm{plant}^{-1}$, respectively, which corresponded to significant increases of $45.1 \%, 80.6 \%$ and $78.8 \%, 99.7 \%$, compared to 32.99 and $5.04 \mathrm{~g} \mathrm{plant}^{-1}$ in the unamended soil. The increments in leaves and cob dry matter were $39.9 \%, 47.1 \%, 71.8 \%$, and $81.7 \%$ and $70.0 \%, 114.6 \%$, $225.4 \%$, and $354.5 \%$ at $30,75,150$, and $300 \mathrm{t} \mathrm{ha}^{-1}$ DMA rates, respectively, as compared to the unamended soil.

3.4. Metals Uptake of Grain in Maize. The effect of dairy manure combined with green manuring on metal 


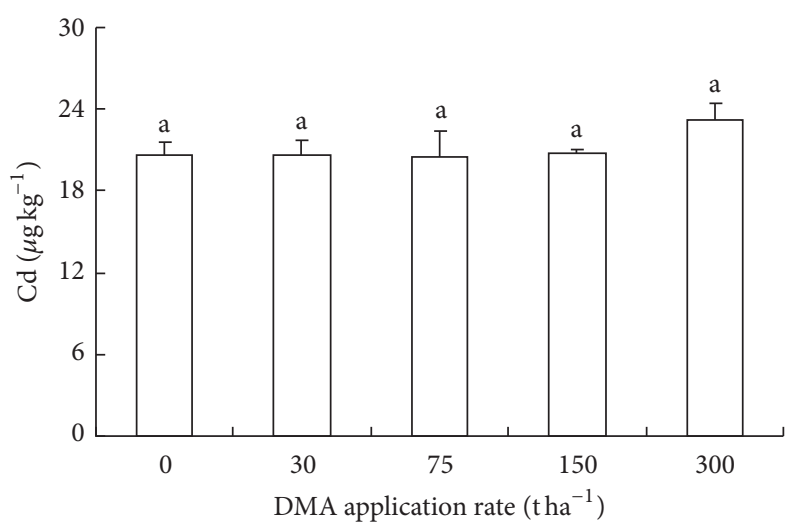

(a)

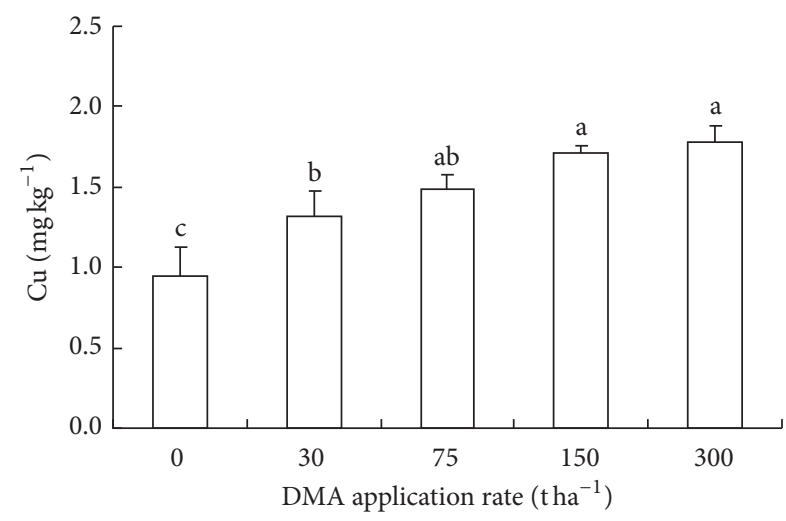

(c)

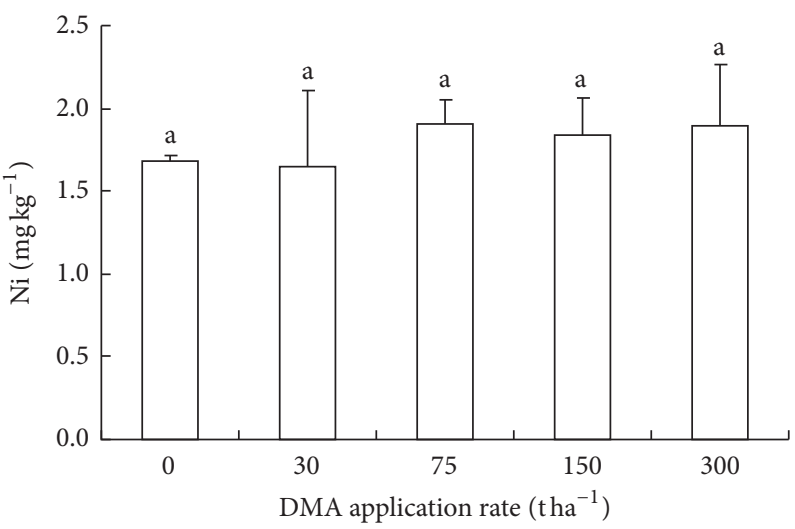

(e)

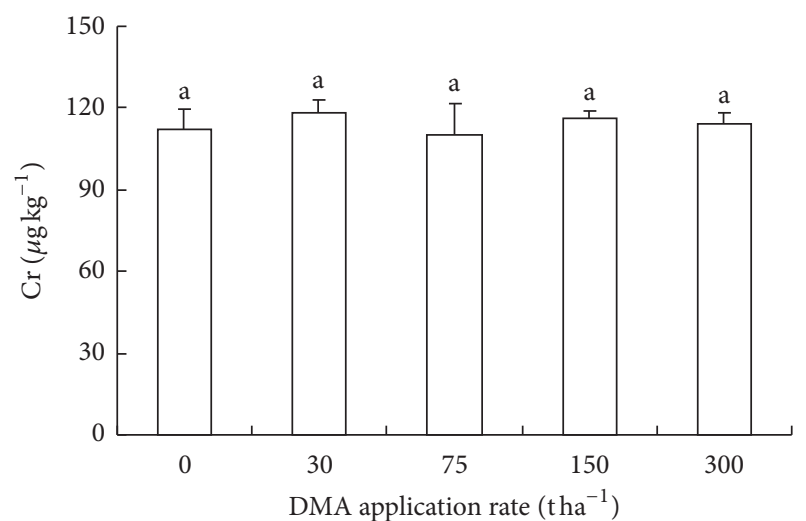

(b)

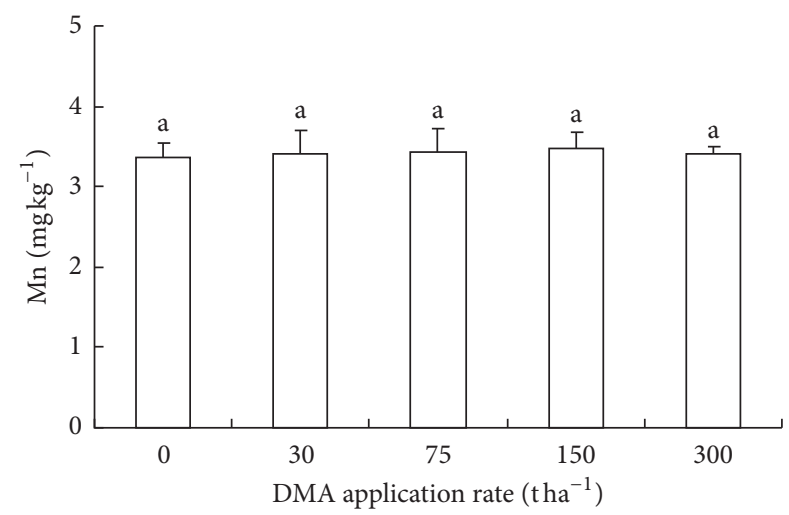

(d)

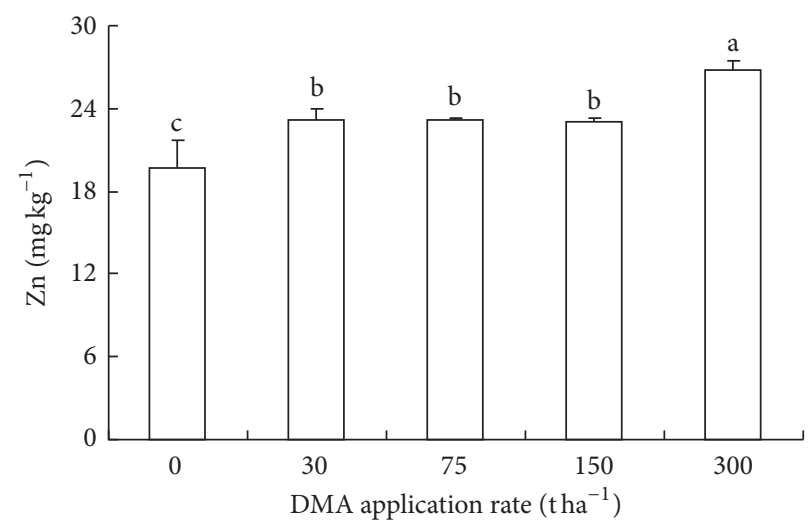

(f)

FIGURE 6: Effects of dairy manure amendment (DMA) on heavy metals concentration for Cd (a), Cr (b), Cu (c), Mn (d), Ni (e), and Zn (f) of maize grain. Vertical bars indicate standard deviations of the means. Columns with different letters show significant difference between dairy manure amendment rates at $p<0.05$ by LSD's multiple range test. $\mathrm{Cd}$, cadmium; $\mathrm{Cr}$, chromium; $\mathrm{Cu}$, copper; $\mathrm{Mn}$, manganese; $\mathrm{Ni}$, nickel; $\mathrm{Zn}$, zinc.

concentrations in grain of maize was shown in Figure 6. $\mathrm{Cu}$ and $\mathrm{Zn}$ concentrations in grain of maize significantly increased with increasing DMA rates. The increments in $\mathrm{Cu}$ and $\mathrm{Zn}$ concentrations in grain of maize were $39.4 \%, 57.3 \%$, $81.8 \%$, and $88.3 \%$ and $17.3 \%, 17.3 \%, 16.8 \%$, and $35.7 \%$ at 30 , 75,150 , and $300 \mathrm{tha}^{-1}$ DMA rates, respectively, as compared to the unamended soil. $\mathrm{Cd}, \mathrm{Cr}, \mathrm{Mn}$, and $\mathrm{Ni}$ concentrations in grain of maize showed no significant changes $(p>0.05)$ between all the treatments.

\section{Discussion}

The one-time application of dairy manure improved initial fertility formation for infertile mudflat saline soil and promoted growth of ryegrass as the first season green manure. The unamended mudflat saline soil is not suitable for ryegrass growth due to its high salinity and low organic matter content $[13,22]$. The present study showed that the one-time application of dairy manure rapidly decreased soil salinity 
and increased soil organic matter in mudflat saline soil, which provided good conditions for growth of ryegrass as first green manure. In addition, mudflat saline soil was enriched with alkaline $\mathrm{N}$, available $\mathrm{P}$, and other nutrients from DMA, which provided sufficient nutrients for ryegrass growth as the first green manure. Previous studies also found that DMA increased biomass of sorghum-sudangrass [23], pasture grass, and ryegrass [24] grown in croplands.

Biomass of ryegrass, Sesbania, and ryegrass as green manures for three consecutive seasons, tilled into the mudflat saline soil, can be decomposed and converted into soil organic carbon, which subsequently improved the chemical properties of mudflat saline soil. In the present study, OC concentration in mudflat saline soil during the 2-year experimental period increased over time and also increased with increasing DMA rates, which were 3.6, 3.7, 5.2, and 5.7 -fold increase at $30,75,150$, and $300 \mathrm{tha}^{-1}$ DMA rates, respectively, compared to $1.705 \mathrm{~g} \mathrm{~kg}^{-1}$ in the unamended soil at the beginning of this study. In addition, OC concentration in the control soil also increased over time, which is due to added organic matter from green manures, but to a lesser extent during the 2-year experimental period by 3.4fold increase compared to the control at the beginning of this study. The OC concentrations in mudflat saline soil at all DMA rates were following the increasing trend of tilled total biomass of green manures. Previous studies in cropland showed that tilled green manure increased soil OC concentration [25] and then improved soil aggregation status and decreased the bulk density [9], increased porosity [26], and saturated hydraulic conductivity [27]. Therefore, salinity reduction of mudflat saline soil might be attributed to the fact that $\mathrm{OM}$ enrichment by dairy manure combined with green manuring reduced soil bulk density, broke soil capillary, and suppressed salt solution rise through soil capillary [28, 29].

The $\mathrm{pH}$ of mudflat saline soil did not show significant variation by one-time application of dairy manure. Previous studies also found that soil $\mathrm{pH}$ did not change by dairy manure application in Calcareous soil [30] and Plano soil [31]. Other studies showed that dairy manure application increased $\mathrm{pH}$ value of alum shale soil [32] and Rosholt soil [31]. The various effects of DMA on soil $\mathrm{pH}$ might be due to original soil $\mathrm{pH}, \mathrm{OM}$ content, and soil buffering capacity. In this study, the $\mathrm{pH}$ of mudflat saline soil significantly decreased after green manuring with Sesbania, and the decrement increased with tilling total biomass of Sesbania. It might be due to proton release from roots during cultivation of legumes and decomposition of organic $\mathrm{N}$ after legumes being tilled [33-35]. Souza et al. [36] also confirmed green manuring with legumes in precrops decreased soil $\mathrm{pH}$.

The dairy manure combined with green manuring promoted supply of $\mathrm{N}$ and $\mathrm{P}$ nutrients in mudflat saline soil, which provided sufficient nutrients for the succeeding plant. The nutrients come from two sources. On the one hand, there are high $\mathrm{N}$ and $\mathrm{P}$ concentrations in the dairy manure; on the other hand, planting and tilling green manures might increase $\mathrm{N}$ and $\mathrm{P}$ accumulation in mudflat saline soil. Legume such as Sesbania may accumulate $\mathrm{N}$ through the $\mathrm{N}$ fixation process, thereby supplying $\mathrm{N}$ for the succeeding crop after it is tilled into soil $[37,38]$. Previous studies also found that green manuring with legumes and hairy vetch in precrops significantly increased $\mathrm{N}$ and $\mathrm{P}$ uptake in rice and oat [38, 39]. In the present study, alkaline $\mathrm{N}$ and available $\mathrm{P}$ content in mudflat saline soil during 2-year experimental period increased with increasing tilled biomass of green manures. Therefore, the more dairy manure applied, the more biomass of green manures tilled, and the more nutrients held in amended mudflat saline soils.

The dairy manure amendment increased first green manure growth, and green manuring for three consecutive seasons might have enhanced the growth of succeeding maize and increased grain yield of the maize. Previous studies also confirmed that grain yield of maize was significantly enhanced by green manuring $[8,40,41]$. In this study, the $30 \mathrm{tha}^{-1}$ DMA with green manuring significantly increased biomass and grain yield of maize by $79.9 \%$ and $78.6 \%$, respectively. The direct cause of this result was green manuring in the premaize, and planting and tilling green manures improved physicochemical properties of mudflat soil. But the ultimate cause was that DMA decreased salinity and boosted initial fertility for growth of green manures.

The DMA increased $\mathrm{Cu}$ and $\mathrm{Zn}$ concentrations in grain of maize grown in the mudflat saline soil. Brock et al. [42] also confirmed that the application of dairy manure increased $\mathrm{Cu}$ and $\mathrm{Zn}$ uptake in maize. Previous studies found that the dairy manure increased $\mathrm{Cu}$ and $\mathrm{Zn}$ concentration in wheat and barley [32]. In the present study, the increment of $\mathrm{Cu}$ and $\mathrm{Zn}$ concentration in grain of maize at DMA rates was $39.4-88.3 \%$ and $17.3-35.7 \%$ compared with the unamended saline soil, which can be attributed to total $\mathrm{Cu}$ and $\mathrm{Zn}$ concentrations in dairy manure used in this study being 48.4 and 2.6-times higher than those in mudflat saline soil. Both $\mathrm{Cu}$ and $\mathrm{Zn}$ are usually added to most dairy rations as part of a mineral mix [42]. Cd, Cr, Mn, and Ni concentrations in grain of maize did not show significant changes between DMA and the control, which was due to the fact that $\mathrm{Cd}$, $\mathrm{Cr}, \mathrm{Mn}$, and $\mathrm{Ni}$ concentrations in the dairy manure were similar to the mudflat soil, and addition of dairy manure did not elevate the concentrations of these metals although it may increase total amount of these metals. In this study, concentrations of heavy metal in grain of maize did not exceed the safety standard for food in China (GB 2762-2012). Therefore, dairy manure combined with green manuring can improve mudflat saline soil chemical properties without compromising environmental safety for heavy metals in crops grown in mudflats. The high input of dairy manure did introduce high amount of nitrogen to the mudflat soil, which may cause environmental concerns. $\mathrm{N}$ in dairy manure was mostly in organic form and its release process was slower in mudflat soil than that in fertile farmland. Attention should however be paid to the environmental risk in future research.

\section{Conclusions}

One-time application of dairy manure for infertile mudflat saline soil promoted growth of ryegrass as the first season green manure. Ryegrass after tilling can be decomposed and converted into soil organic carbon. By the cycles of the 
planting and tilling ryegrass, Sesbania, and ryegrass as green manures for three consecutive seasons, it rapidly improved the chemical properties of mudflat saline soil by decreasing soil salinity and $\mathrm{pH}$ and increasing soil organic carbon and available $\mathrm{N}$ and $\mathrm{P}$. As a result, dry matter of maize plant parts increased with increasing DMA rates. $\mathrm{Cu}$ and $\mathrm{Zn}$ concentrations in grain of maize at DMA rates were higher than those in the unamended soil, whereas there were no significant differences $(p>0.05)$ of $\mathrm{Cd}, \mathrm{Cr}, \mathrm{Mn}$, and $\mathrm{Ni}$ concentrations in grain of maize in the DMA soils, compared to the unamended soil. Dairy manure combined with green manuring can be applied for mudflat saline soil amendment, which is a potential win-win solution with respect to new arable land creating, waste disposal, and resource recycling.

\section{Competing Interests}

The authors declare that there is no conflict of interests regarding the publication of this paper.

\section{Acknowledgments}

This study is supported by National Natural Science Foundation of China (31101604), Fund for Agricultural Independent Innovation of Jiangsu Province [CX(15)1005], Postdoctoral Science Foundation of China (2016M601755), Fund for Ministry of Science and Technology of China (2015BAD01B03), Fund for Important Research and Development of Jiangsu Province (BE2015337), Fund for State Key Laboratory of Soil and Sustainable Agriculture (Y412201402), Fund for Ministry of Housing and Urban-Rural Department of China (2014-K6-009), Fund for Three New Agricultural Project of Jiangsu Province (SXGC[2016]277), Fund for Environmental Protection of Yangzhou City (YHK1414), and Shuangchuang Talent Plan of Jiangsu Province, China.

\section{References}

[1] F. Wang and G. Wall, "Mudflat development in Jiangsu Province, China: practices and experiences," Ocean and Coastal Management, vol. 53, no. 11, pp. 691-699, 2010.

[2] W. Cao and M. H. Wong, "Current status of coastal zone issues and management in China: a review," Environment International, vol. 33, no. 7, pp. 985-992, 2007.

[3] D. Song, X. H. Wang, X. Zhu, and X. Bao, "Modeling studies of the far-field effects of tidal flat reclamation on tidal dynamics in the East China Seas," Estuarine, Coastal and Shelf Science, vol. 133, pp. 147-160, 2013.

[4] K. Guo and X. Liu, "Dynamics of meltwater quality and quantity during saline ice melting and its effects on the infiltration and desalinization of coastal saline soils," Agricultural Water Management, vol. 139, pp. 1-6, 2014.

[5] Y. Bai, C. Gu, T. Tao, L. Wang, K. Feng, and Y. Shan, "Growth characteristics, nutrient uptake, and metal accumulation of ryegrass (Lolium perenne L.) in sludge-amended mudflats," Acta Agriculturae Scandinavica Section B: Soil and Plant Science, vol. 63, no. 4, pp. 352-359, 2013.

[6] R. J. Yao, J. S. Yang, D. H. Wu, W. P. Xie, P. Gao, and X. P. Wang, "Characterizing spatial-temporal changes of soil and crop parameters for precision management in a coastal rainfed agroecosystem," Agronomy Journal, vol. 108, no. 6, p. 2462, 2016.

[7] R. J. Yao, J. S. Yang, P. Gao, J. B. Zhang, and W. H. Jin, "Determining minimum data set for soil quality assessment of typical salt-affected farmland in the coastal reclamation area," Soil and Tillage Research, vol. 128, pp. 137-148, 2013.

[8] T. O. Fabunmi, M. U. Agbonlahor, J. N. Odedina, and S. O. Adigbo, "Profitability of pre-season green manure practices using maize as a test crop in a derived savanna of Nigeria," Pakistan Journal of Agricultural Sciences, vol. 49, no. 4, pp. 593596, 2012.

[9] M. Wiesmeier, M. Lungu, R. Hübner, and V. Cerbari, "Remediation of degraded arable steppe soils in Moldova using vetch as green manure," Solid Earth, vol. 6, no. 2, pp. 609-620, 2015.

[10] R. V. Valadares, R. F. Duarte, J. B. C. Menezes et al., "Soil fertility and maize yields in green manure systems in northern Minas Gerais," Planta Daninha, vol. 30, no. 3, pp. 505-516, 2012.

[11] L. Talgre, E. Lauringson, H. Roostalu, A. Astover, and A. Makke, "Green manure as a nutrient source for succeeding crops," Plant, Soil and Environment, vol. 58, no. 6, pp. 275-281, 2012.

[12] T. Jun, G. Wei, B. Griffiths, L. Xiaojing, X. Yingjun, and Z. Hua, "Maize residue application reduces negative effects of soil salinity on the growth and reproduction of the earthworm Aporrectodea trapezoides, in a soil mesocosm experiment," Soil Biology and Biochemistry, vol. 49, pp. 46-51, 2012.

[13] T. Zhang, T. Wang, K. S. Liu, L. Wang, K. Wang, and Y. Zhou, "Effects of different amendments for the reclamation of coastal saline soil on soil nutrient dynamics and electrical conductivity responses," Agricultural Water Management, vol. 159, pp. 115122, 2015.

[14] L. Wu, M. Cheng, Z. Li et al., "Major nutrients, heavy metals and PBDEs in soils after long-term sewage sludge application," Journal of Soils and Sediments, vol. 12, no. 4, pp. 531-541, 2012.

[15] R. A. Blaustein, R. L. Hill, S. A. Micallef, D. R. Shelton, and Y. A. Pachepsky, "Rainfall intensity effects on removal of fecal indicator bacteria from solid dairy manure applied over grasscovered soil," Science of the Total Environment, vol. 539, pp. 583591, 2016.

[16] P. J. A. Kleinman, P. Salon, A. N. Sharpley, and L. S. Saporito, "Effect of cover crops established at time of corn planting on phosphorus runoff from soils before and after dairy manure application," Journal of Soil and Water Conservation, vol. 60, no. 6, pp. 311-322, 2005.

[17] A. N'Dayegamiye, "Response of silage corn and wheat to dairy manure and fertilizers in long-term fertilized and manured trials," Canadian Journal of Soil Science, vol. 76, no. 3, pp. 357363, 1996.

[18] F. Domingo-Olivé, À. D. Bosch-Serra, M. R. Yagüe, R. M. Poch, and J. Boixadera, "Long term application of dairy cattle manure and pig slurry to winter cereals improves soil quality," Nutrient Cycling in Agroecosystems, vol. 104, no. 1, pp. 39-51, 2016.

[19] D. H. Min, K. R. Islam, L. R. Vough, and R. R. Weil, "Dairy manure effects on soil quality properties and carbon sequestration in alfalfa-orchardgrass systems," Communications in Soil Science and Plant Analysis, vol. 34, no. 5-6, pp. 781-799, 2003.

[20] C. Mallol, "What's in a beach? Soil micromorphology of sediments from the Lower Paleolithic site of 'Ubeidiya, Israel," Journal of Human Evolution, vol. 51, no. 2, pp. 185-206, 2006.

[21] S. D. Bao, Soil and Agro-Chemistry Analysis, China Agricultural Press, Beijing, China, 3rd edition, 2000. 
[22] Y. Bai, T. Tao, C. Gu, L. Wang, K. Feng, and Y. Shan, "Mudflat soil amendment by sewage sludge: soil physicochemical properties, perennial ryegrass growth, and metal uptake," Soil Science and Plant Nutrition, vol. 59, no. 6, pp. 942-952, 2013.

[23] H. M. Waldrip, Z. He, and T. S. Griffin, "Effects of organic dairy manure on soil phosphatase activity, available soil phosphorus, and growth of Sorghum-Sudangrass," Soil Science, vol. 177, no. 11, pp. 629-637, 2012.

[24] D. Espinosa, P. W. G. Sale, and C. Tang, "Changes in pasture root growth and transpiration efficiency following the incorporation of organic manures into a clay subsoil," Plant and Soil, vol. 348, no. 1-2, pp. 329-343, 2011.

[25] M. A. Rudisill, B. P. Bordelon, R. F. Turco, and L. A. Hoagland, "Sustaining soil quality in intensively managed high tunnel vegetable production systems: a role for green manures and chicken litter," HortScience, vol. 50, no. 3, pp. 461-468, 2015.

[26] W. T. Jeon, B. Choi, S. A. M. Abd El-Azeem, and Y. S. Ok, "Effect of different seeding methods on green manure biomass, soil properties and rice yield in rice-based cropping systems," African Journal of Biotechnology, vol. 10, no. 11, pp. 2024-2031, 2011.

[27] K. Panitnok, S. Thongpae, E. Sarobol et al., "Effects of vetiver grass and green manure management on properties of map bon, coarse-loamy variant soil," Communications in Soil Science and Plant Analysis, vol. 44, no. 1-4, pp. 158-165, 2013.

[28] M. H. Jorenush and A. R. Sepaskhah, "Modelling capillary rise and soil salinity for shallow saline water table under irrigated and non-irrigated conditions," Agricultural Water Management, vol. 61, no. 2, pp. 125-141, 2003.

[29] R.-J. Yao, J.-S. Yang, T.-J. Zhang et al., "Studies on soil water and salt balances and scenarios simulation using SaltMod in a coastal reclaimed farming area of eastern China," Agricultural Water Management, vol. 131, pp. 115-123, 2014.

[30] A. B. Leytem, R. S. Dungan, and A. Moore, "Nutrient availability to corn from dairy manures and fertilizer in a calcareous soil," Soil Science, vol. 176, no. 8, pp. 426-434, 2011.

[31] Z. Wu and J. M. Powell, "Dairy manure type, application rate, and frequency impact plants and soils," Soil Science Society of America Journal, vol. 71, no. 4, pp. 1306-1313, 2007.

[32] A. K. M. Arnesen and B. R. Singh, "Plant uptake and DTPAextractability of $\mathrm{Cd}, \mathrm{Cu}, \mathrm{Ni}$ and $\mathrm{Zn}$ in a Norwegian alum shale soil as affected by previous-addition of dairy and pig manures and peat," Canadian Journal of Soil Science, vol. 78, no. 3, pp. 531-539, 1998.

[33] F. Yan, S. Schubert, and K. Mengel, "Soil pH changes during legume growth and application of plant material," Biology and Fertility of Soils, vol. 23, no. 3, pp. 236-242, 1996.

[34] F. Yan, S. Schubert, and K. Mengel, "Soil pH increase due to biological decarboxylation of organic anions," Soil Biology and Biochemistry, vol. 28, no. 4-5, pp. 617-624, 1996.

[35] S. Pocknee and M. E. Sumner, "Cation and nitrogen contents of organic matter determine its soil liming potential," Soil Science Society of America Journal, vol. 61, no. 1, pp. 86-92, 1997.

[36] J. L. Souza, G. P. Guimarães, and L. F. Favarato, “Development of vegetables and soil characteristics after green manuring and organic composts under levels of N," Horticultura Brasileira, vol. 33, no. 1, pp. 19-26, 2015.

[37] L. O. Brandsæter, H. Heggen, H. Riley, E. Stubhaug, and T. M. Henriksen, "Winter survival, biomass accumulation and $\mathrm{N}$ mineralization of winter annual and biennial legumes sown at various times of year in Northern Temperate Regions," European Journal of Agronomy, vol. 28, no. 3, pp. 437-448, 2008.
[38] Z. Shah, S. R. Ahmad, and H. U. Rahman, "Sustaining ricewheat system through management of legumes I: effect of green manure legumes on rice yield and soil quality," Pakistan Journal of Botany, vol. 43, no. 3, pp. 1569-1574, 2011.

[39] A. Tarui, A. Matsumura, S. Asakura, K. Yamawaki, R. Hattori, and H. Daimon, "Evaluation of mixed cropping of oat and hairy vetch as green manure for succeeding corn production," Plant Production Science, vol. 16, no. 4, pp. 383-392, 2013.

[40] G. S. A. Castro and C. A. C. Crusciol, "Effects of surface application of dolomitic limestone and calcium-magnesium silicate on soybean and maize in rotation with green manure in a tropical region," Bragantia, vol. 74, no. 3, pp. 311-321, 2015.

[41] J.-S. Bai, W.-D. Cao, J. Xiong, N.-H. Zeng, S.-J. Gao, and S. Katsuyoshi, "Integrated application of February Orchid (Orychophragmus violaceus) as green manure with chemical fertilizer for improving grain yield and reducing nitrogen losses in spring maize system in northern China," Journal of Integrative Agriculture, vol. 14, no. 12, pp. 2490-2499, 2015.

[42] E. H. Brock, Q. M. Ketterings, and M. McBride, "Copper and zinc accumulation in poultry and dairy manure-amended fields," Soil Science, vol. 171, no. 5, pp. 388-399, 2006. 


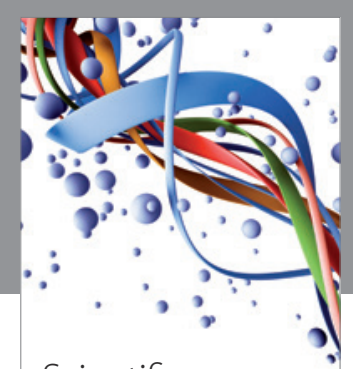

Scientifica
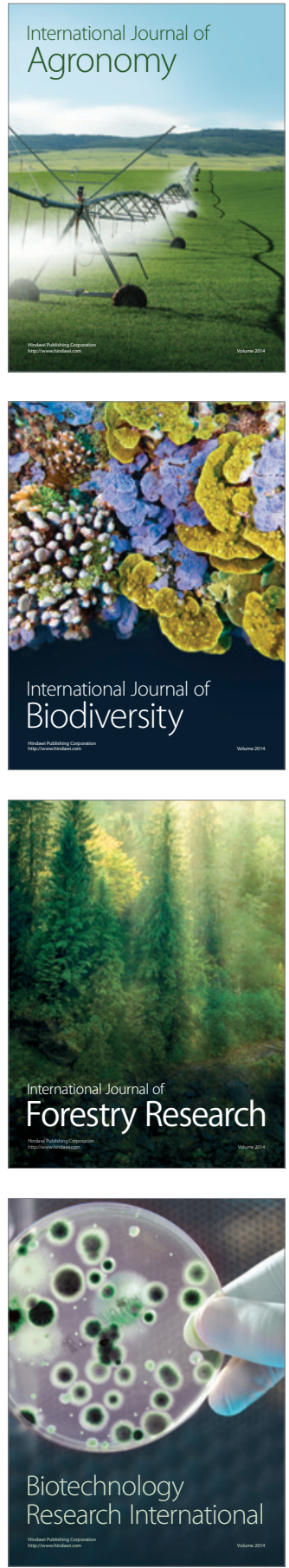
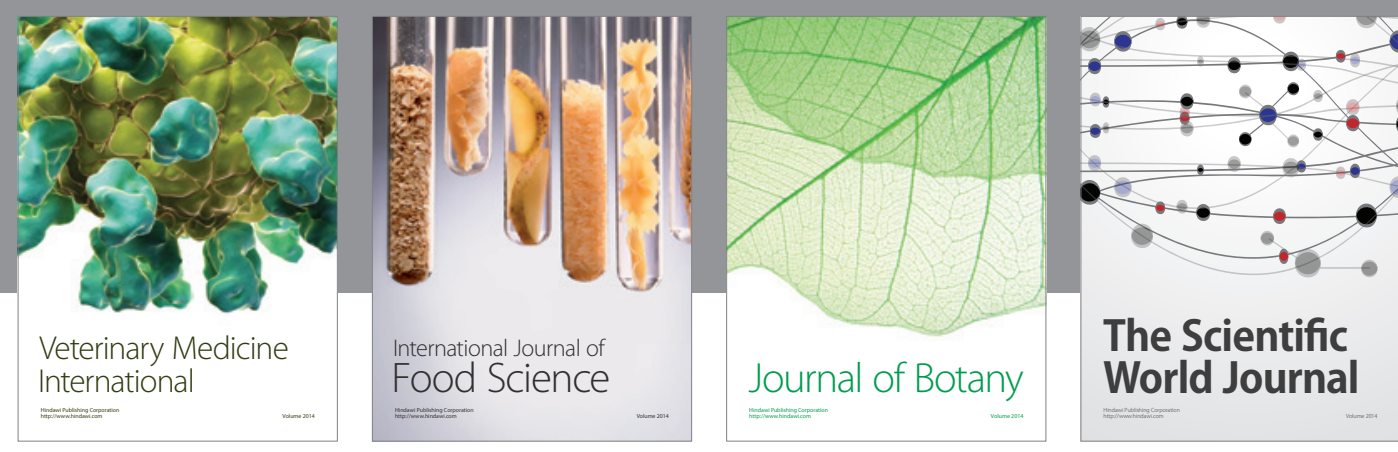

The Scientific

\section{World Journal}

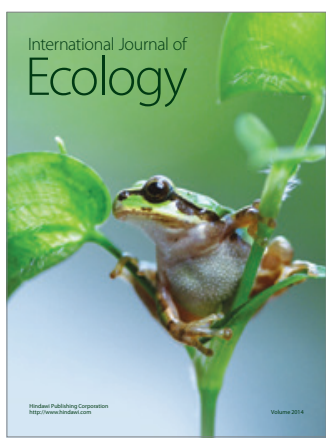

\section{Hindawi}

Submit your manuscripts at

https://www.hindawi.com
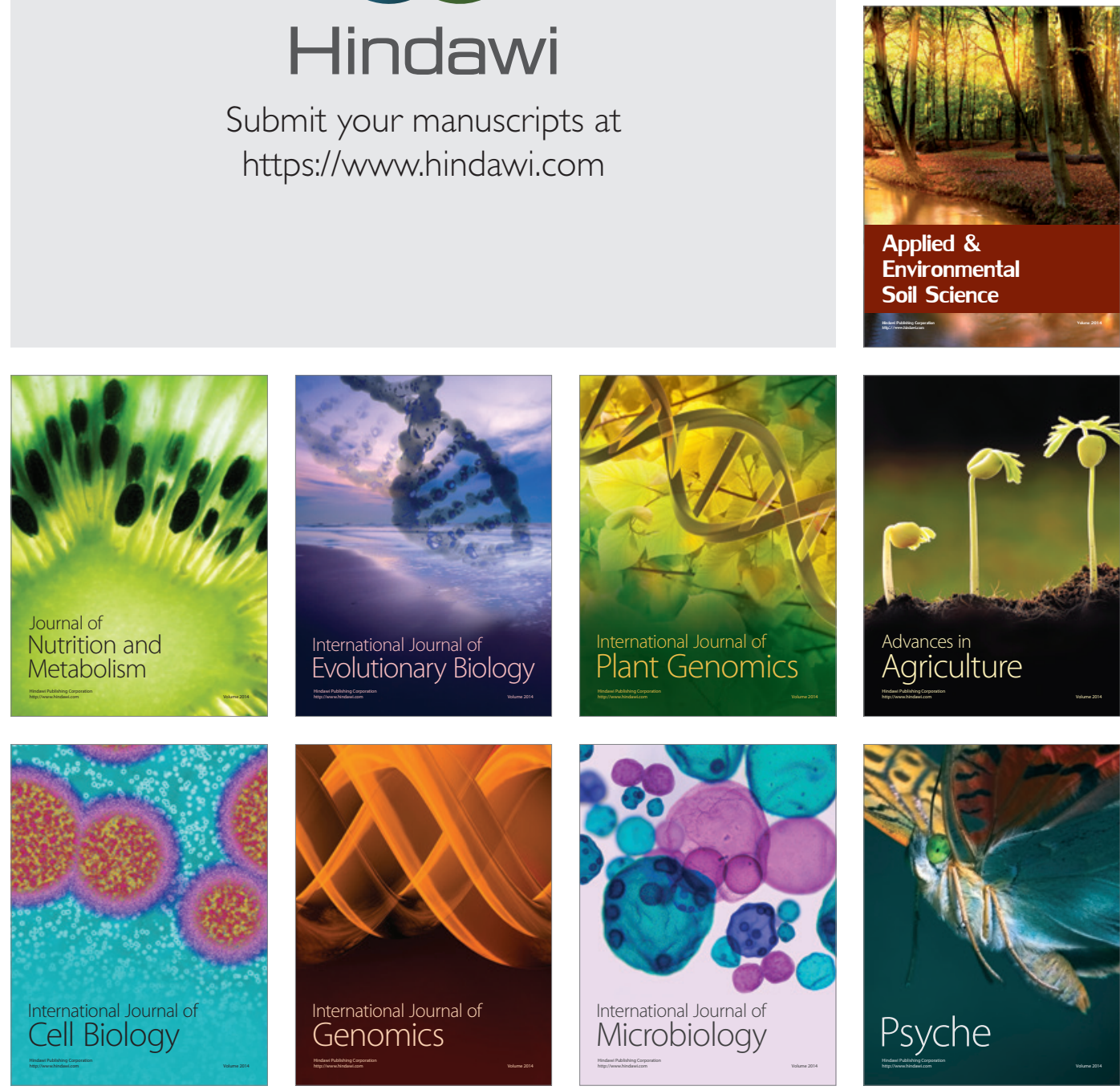
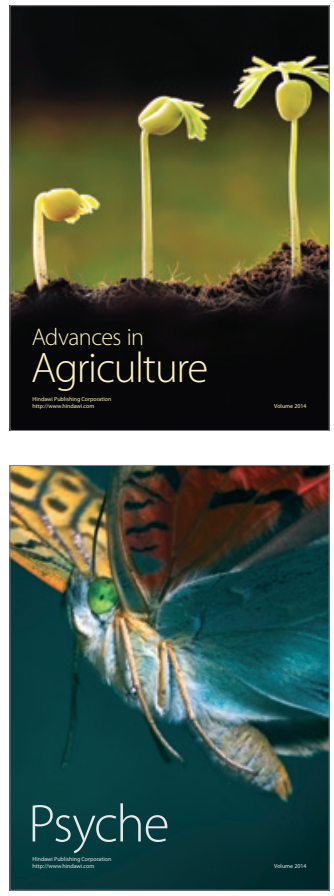